\title{
Bilirubin metabolism and its role in atherosclerosis
}

\section{Bilirubin metabolizması ve aterosklerozdaki rolü}

\author{
Necat Yılmaz ${ }^{1}$, Cemile Öz ${ }^{2}$, Esin Eren ${ }^{1}$, Seçkin Özgür Tekeli ${ }^{2}$
}

\begin{abstract}
Hemoglobin is not an guiltless bystander of the pathophysiology in a number of atherosclerotic diseases. Heme, which is released from hemoglobin or other heme proteins, triggers various pathophysiological consequence, including heme stress as well as intracellular stress. Although heme serves key functions and is tightly controlled, high levels of free heme, which may occur in various pathophysiological conditions, are may hazardous via pro-oxidant, pro-inflammatory, and cytotoxic effects.

Heme oxygenases are heat shock protein enzymes that use heme as a substrate and function as an essential antioxidant adaptive response by all human cells. A major function of heme oxygenases is clearance of heme that accumulate in tissues due to erythrocyte turnover. The potentially toxic free heme is converted by heme oxygenases into carbon monoxide, iron, and biliverdin, the third of which is reduced to bilirubin. In literature the heme degradation pathway has been demonstrated to play a protective role against the development of atherosclerosis. Because growing evidence suggests that oxidative stress is involved in atherosclerosis.

This review documents the roles of bilurubin in atherosclerosis and focuses on the clinical significance as a potential therapeutic target in atherosclerotic diseases, such as coronary artery disease.
\end{abstract}

Keywords ; Bilirubin, Atherosclerosis, Heme oxygenases, Oxidative stress, Cardiovascular diseases.

Öz

Hemoglobin bir dizi aterosklerotik hastalığın patofizyolojisinde suçsuz bir seyirci değildir. Hemoglobinden veya diğer hem proteinlerinden salınan hem hücre içi stresin yanında hem stresi de dahil olmak üzere çeşitli patofizyolojik sonuçları tetikler. Hemin anahtar fonksiyonları olması ve sıkı bir şekilde kontrol edilmesine rağmen, çeşitli patofizyolojik koşullarda ortaya çıkabilen yüksek serbest heme seviyeleri, pro-oksidan, proenflamatuar ve sitotoksik etkiler nedeniyle tehlikeli olabilir.

Hem oksijenazlar, hemi bir substrat olarak kullanan ve tüm insan hücreleri tarafindan gerekli bir antioksidan adaptif yanıt olarak işlev gören 1sı şoku protein enzimleridir. Hem oksijenazların en önemli fonksiyonu eritrosit döngüsüne bağlı dokularda biriken hemin temizlenmesidir. Potansiyel toksik serbest hem hem oksijenazları tarafindan karbon monoksit, demir ve biliverdine dönüştürülür, bunlardan üçüncüsü bilirubine indirgenir. Literatürde hem degradasyon yolunun ateroskleroz gelişimine karşı koruyucu bir rol oynadığı gösterilmiştir. Çünkü artan kanıtlar oksidatif stresin aterosklerozda rol oynadığını düşündürmektedir.

$\mathrm{Bu}$ derleme bilurubinin aterosklerozdaki rollerini belgelemekte ve koroner arter hastalığı gibi aterosklerotik hastalıklarda potansiyel bir terapötik hedef olarak klinik öneme odaklanmaktadır.

Anahtar Kelimeler; Bilirubin, Ateroskleroz, Hem oksijenaz, Oksidatif stres, Kardiyovasküler hastalıklar
${ }^{1}$ University of Health Sciences, Antalya Training and Research Hospital, Department of Medical Biochemistry and LC/MS-MS Laboratory, Antalya, Turkey.

${ }^{2}$ University of Health Sciences Antalya Training and Research Hospital, Department of Medical Biochemistry, Antalya, Turkey.

\section{iD}

NY: 0000-0002-3865-9156

CÖ: 0000-0001-7835-7454

EE: 0000-0001-9780-2437 SÖT: 0000-0002-4430-1134

Conflict of Interest: No conflict of interest was declared by the authors.

Çıkar Çatışması: Yazarlar çıkar çatışması bildirmemișlerdir.

Financial Disclosure: The authors declared that this study has received no financial support.

Finansal Destek: Yazarlar bu çalışma için finansal destek almadıklarını beyan etmișlerdir.

Geliş Tarihi / Received: 07.03.2020

Kabul Tarihi / Accepted: 14.07.2020

Yayın Tarihi / Published: 31.08.2020

Sorumlu yazar / Corresponding author:

Necat Yilmaz

Adres/Address: Saglik Bilimleri Universitesi Antalya Egitim ve Arastirma Hastanesi, Tibbi Biyokimya Anabilim Dali ve LC/MS-MS Laboratuvarı, Varlik Mahallesi, Kazım Karabekir Caddesi, 07100, Muratpasa, Antalya, Turkey.

e-posta: necatyilmaz@hotmail.com

Tel/Phone: +905053578305

Copyright $(\mathcal{C}$ ACEM 
In this review we aimed to examine several experimental and clinical studies investigating the relationship between atherosclerotic diseases and bilirubin and the effects of bilirubin on the atherosclerotic process. It is known that oxidative stress is involve in atherosclerosis. Heme degradation pathway which bilirubin is synthesised has been demonstrated to play a protective role against the development of atherosclerosis. The protective properties of bilirubin are observed at every stage of the atherosclerosis process. This review documents the roles of bilurubin in atherosclerosis and focuses on the clinical significance as a potential therapeutic target in atherosclerotic diseases.

\section{Bilirubin}

Bilirubin become of four pyrrole rings, both connected by carbon bridges formed during its catabolism. From an evolutionary perspective, protoporphyrin ring is a exclusive metal chelator with outstanding properties. In contrast, for many years, bilirubin had been thought to be a toxic waste product, especially for the central nervous system [1]. Thus bilirubin often has been considered as a metabolic waste. However, recent evidence suggests that bilirubin may have many other beneficial effects, including anti-oxidant effects, anti-inflammatory effects, and direct effects on cell signaling [2]. Today many epidemiological data highlight that bilirubin may play a protective role against atherosclerosis [1].

\section{Bilirubin Synthesis}

The bulk of bilirubin is caused by the breakdown of red blood cells that fill its life. Approximately $85 \%$ of total bilirubin is originated from hemoglobin in mature red blood cells destroyed in reticuloendothelial cells. The remaining $15 \%$ consists of immature red blood cells that break down in the bone marrow and other molecules such as; myoglobin, cytochromes, catalase and peroxidase [3]. When both pathways reach the oxygenase enzyme system, iron is usually upgraded to ferric $(\mathrm{Fe}+3)$ form and Hemin is formed. Hemin is reduced to NADPH, switching to become iron ferro $(\mathrm{Fe}+2)$ form. Then porphyria with more oxygen is added to the alpha text bridge between the pyrrole rings, and ferro iron is oxidized again in the form of ferri. Finally with the addition of oxygen, iron is released, carbonmonoxide is formed, biliverdin is revealed. Biliverdin by reducing the text bridge between the pyrrole rings to the methylene group, it forms bilirubin, a yellow pigment [4]. Bilirubin formation pathways are shown in figure 1 .

Figure 1. Bilirubin synthesis.

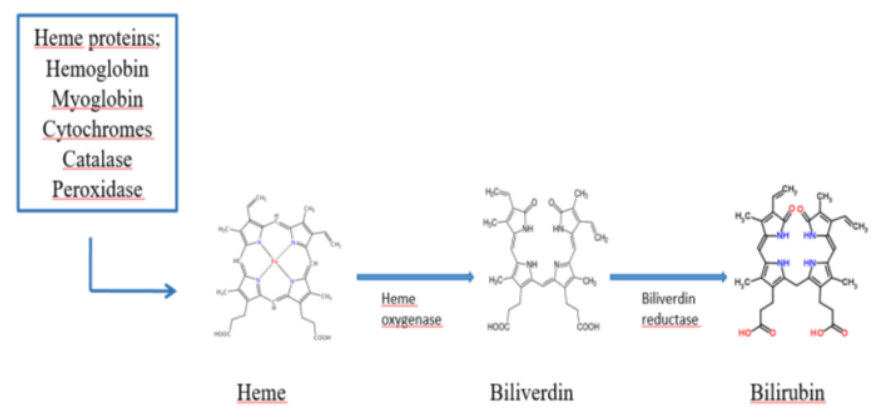

The first formed bilirubin is known as indirect bilirubin (free bilirubin, unkonjuge bilirubin). Indirect bilirubin is insoluble in water, does not pass through urine and is not excreted with bile. Unconjuge bilirubin is usually carried to the liver through circulation by binding to albumin [3]. Serum albumin-bound bilirubin comes to liver, leaving albumin in the hepatocyte sinusoidal membrane and passing through the membrane. Bilirubin entering the liver cell binds reversibl to soluble proteins known as Ligandins or Protein Y (glutathione-Stransferase gene family). Hepatocytes add glucuronic acid molecules to bilirubin, transforming it into a polar form conjuge bilirubine that can be easily excreted into bile. This process is called conjugation. The conjugation of bilirubin is catalysed by a specific glucuronosyltransferase in the endoplasmic reticulum, uses UDP-glucuronic acid as the glucronosyl transmitter, and is defined as bilirubin-UGT [3] (Figure 2).

Firstly bilirubin monoglucuronide is an intermediate and then decoded into diglucuronide. Most of bilirubin thrown into bile is in the form of bilirubin diglucuronide. However, when bilirubin conjugates are abnormally present in human plasma, they are mostly in the form of monoglucuronids. Conjugated bilirubinin secretion of bile is known as the ratelimiting step in bilirubin metabolism. This transport process takes place through the active transport mechanism via MRP-2 (multidrug resistance-like protein 2). When conjugated bilirubin reaches the terminal ileum and large intestine, glucronides with $\beta$-glucronidases are removed and urobilinogens, which are colorless tetrapyrol compounds, are formed [4].

Under physiological conditions, the dominant circulation form of bilirubin is the un-conjugated albumin-bound form but four forms of bilirubin have been isolated in the serum. Non conjugated-bilirubin ( $\alpha$-bilirubin) 27\%, mono-conjugated bilirubin ( $\beta$-bilirubin) 24\%, conjugated bilirubin, Di bilirubin $(\gamma-$ bilirubin) $13 \%$ protein, which is connected and $37 \%$ irreversible bilirubin ( $\delta$-bilirubin) in serum. Antioxidant activity and cardioprotective potential can be attributed to any of the bilirubin forms [5].

\section{Endogenous Antioxidant Effects Of Bilirubin}

Bilirubin was for many years considered a waste product of oxygenases. While much attention was not shown to the physiological roles of bilirubin until the 1987 year studies showing that bilirubin suppresses the oxidation of peroxyl radicals more than $\alpha$-tocopherol [6]. Today, bilirubin's antioxidant potential has been confirmed by additional studies; it has been shown that bilirubin is 20 times more effective in preventing LDL oxidation than Trolox [7]. It has also been reported that non-conjugated bilirubin concentrations as low as $10 \mathrm{nmol} / \mathrm{L}$ protect neuronal cultures from oxidative stress [8]. Nowadays bilirubin is considered the most potent endogenous antioxidant due to its continuous improvement in the bilirubin / biliverdin redox cycle, resulting in both in vitro and in vivo protective lipid peroxidation. Besides this antioxidative effect, bilirubin also exerts immunosuppressive effects on antigen presenting cells and T cells, as well as on inhibition of adhesion molecule expression and immune cell migration. These concepts might form the basis of a new understanding of bilirubin metabolism, creating a new treatment approach for atherosclerosis, cancer, autoimmune diseases [9].

\section{Bilirubin as an anti-atherogenic molecule}

Undoubtedly atherosclerosis is a leading cause of death in developed and developing countries. Yet, well known labile free heme is one of the many known risk factors for atherosclerosis and contributes to the formation of this complex disease. Nowadays total bilirubin in circulation is known to be inversely and independently associated with the risk of future cardiovascular heart disease (CHD). A large number of clinical trials have strongly demonstrated the protective role of bilirubin against atherosclerotic heart diseases. Undoubtly higher total bilirubin contributes to lower CHD risk [10]. 
Figure 2. Bilirubin diglucuronide synthesis in hepatocytes.

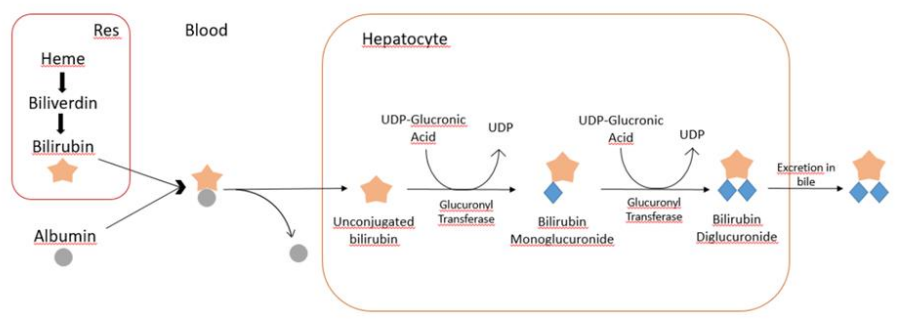

Res: Reticulo-endothelial system, UDP: Uridine diphosphate

In 1994, Schwertner et al. they were the first researchers to report a negative relationship between lower serum bilirubin concentrations and CHD on as many as 900 men. The strength of this relationship was found to be similar to smoking, hypertension and dyslipidemia. In this pioneering study, a $50 \%$ decrease in total bilirubin was associated with a $47 \%$ increase in the likelihood of more severe coronary artery disease, which was proven by coronary angiography [11]. Later, Vitek et al. they started a retrospective study on cases with Gilbert Syndrome, known as benign hyperbilirubinemia and characterized by slightly increased unkonjuge hiperbilirubinemia. Although the cohort was small $(\mathrm{n}=50)$, individuals with benign hyperbilirubinemia were found to have a lowest $2 \%$ prevalence rate for CHD compared with the general population. This study was continued prospectively and patients were followed up for 3 years. While there was a $3,1 \%$ incidence of CHD in control subjects during this period, no cases of were seen in patients with Gilbert Syndrome [12].

A year later, a meta-analysis involving 11 studies by Novotny and Vitek were reported strong negative correlation between serum bilirubin levels and atherosclerosis severity in men $(p<0,0001)$. Also, nonparametric regression analyses have shown a negative relationship between serum bilirubin concentrations and atherosclerotic diseases. In a one study, it was found that every $1,0 \mu \mathrm{mol} / \mathrm{L}$ increase in serum bilirubin was associated with a $6,5 \%$ decrease in cardiovascular disease [13]. The same relationship was also demonstrated in a study on patients with cardiac X syndrome, which was followed up for 5 years. Patients with the lowest serum bilirubin levels were reported to have a higher incidence of hospitalization for nonfatal myocardial infarction, ischemic stroke, unstable angina [14]. Indeed lower serum bilirubin was able to independently estimate long-term mortality in coronary artery disease (CAD) (HR 0.34 , 95\% CI 0.16-0.70) and unstable angina (UAP) (HR $0.49,95 \%$ CI $0.31-0.78)$ groups [15].

It has also been reported to be associated bilirubin with coronary artery calcification (CAC), which is a good indicator of the presence and amount of coronary atherosclerosis. Because in a cross-sectional study of 398 men and 239 women, serum bilirubin concentrations were found to be strongly associated with CAC scores and independent predictors of CAC in both men and women [16]. Similarly in a cross-sectional study conducted on 2682 non-CAD patients for bilirubin was found to be inversely related to total coronary plaque. In this prevalence of coronary atherosclerosis or $>50 \%$ coronary artery stenosis was found to be lower in people with high serum bilirubin levels (>1,2 $\mathrm{mg} / \mathrm{dL})$ than those with normal serum bilirubin levels [17]. As a result; serum bilirubin, creates antioxidantantilipoperoxidative effects in atherosclerotic plaques and appears to be negatively associated with the severity of atherosclerosis [18].
In addition to these studies, there are studies that suggest a relationship between serum bilirubin levels and general mortality [19]. Similarly, in 533 patients with acute coronary syndrome had followed in terms of revascularization and acute heart failure, and it had been concluded that bilirubin was might be associated with a mortality risk at the end of year 2,4. Also many experimental data obtained in animal models strongly supported the protective role of bilirubin [20]. However, clinical studies regarding the prognostic role of total bilirubin in patients with acute myocardial infarction (AMI) in short-term are conflicting. Marginally higher serum total bilirubin level may be a predictor of major cardiac events and cardiovascular death in patients with AMI. Whereas higher baseline bilirubin levels were significantly associated with an increased risk of short-term mortality hazard ratio (HR) 2.35, (95\% confidence interval (CI) 1.15-4.77) in the AMI group [21]. When conflicting results were found in the literature, new studies are required.

Therefore in another one meta-analysis the effect of serum total bilirubin level on the risk of atherosclerotic heart diseases were evaluated. A total of 20 studies (323,891 cases) were included in the meta-analysis and identified as coronary artery disease, acute coronary syndrome, stable angina, coronary revascularization, atherosclerotic stroke or transient ischemic attack, and peripheral artery disease (PAD). This meta-analysis showed that bilirubin was significantly negatively associated with cardiovascular mortality, major adverse cardiac events, and AMI prognosis, bilirubin levels. According to this reported, it can be concluded that higher serum bilirubin showed significant negative relationship with cardiovascular disease $(\mathrm{HR}=0.83$ (95\% CI 0.73-0.94) [22]. Later the relationship between serum bilirubin levels and PAD has also been extensively investigated. Increased serum total bilirubin levels were associated with decreased PAD prevalence. Even the combined analysis showed that lower bilirubin levels were significantly associated with PAD (OR $=0.91$ (95\% CI 0.85-0.98)) [22]. Also in 2008, Perlstein et al. published a retrospective study on more than 7000 adults from the National Health and Nutrition Examination Survey (NHANES). In this study, every $0,1 \mathrm{mg} / \mathrm{dL}(1,7 \mu \mathrm{mol} / \mathrm{L})$ increase in serum bilirubin level after adjustment for possible confounding factors was associated with a $6 \%$ decrease in the incidence of PAD [23].

In addition to PAD research other studies have shown that bilirubin is associated with intracranial atherosclerosis (ICAS). In a population-based study to investigate the epidemiology and natural history of asymptomatic ICAS in middle age and older adults, after adjusting for all contradictions, bilirubin levels were found to be negatively associated with ICAS, especially in individuals over 60 years of age. This result showed that bilirubin can have a protective effect on ICAS, especially in older individuals [24]. Clinical trials of bilirubin and results are given in Table 1.

\section{Bilirubin and metabolic disturbances leading to atherosclerosis}

Considering the atheroprotective effects of bilirubin, it is not surprising that the same negative correlations exist for other diseases commonly associated with atherosclerosis. So there are numerous studies showing that bilirubin levels are associated with metabolic syndrome or diabetes. The first report published in this context was about the association of bilirubin with metabolic syndrome between children and adolescents. Furthermore, in diabetic rats, up-regulation of heme oxygenases 1 increases serum bilirubin, reduces superoxide anion and endothelial sloughing induced by hyperglycemia [19].This graded relationship was also significantly preserved after the adjustment of other co-variables [25]. Another important study 
Table 1:Clinical studies for bilirubin and atherosclerotic heart disases.

\begin{tabular}{|c|c|c|c|c|}
\hline Studies & $\begin{array}{l}\text { Participants of } \\
\text { study }\end{array}$ & $\mathrm{n}$ & Change of parameters & Results \\
\hline $\begin{array}{l}\text { Schwertner H } \\
\text { et al. } 1994\end{array}$ & $\begin{array}{l}\text { Coronary artery } \\
\text { disease }(\mathrm{CAD})\end{array}$ & 900 & $\begin{array}{l}\% 50 \text { decreases in Total } \\
\text { bilirubin }\end{array}$ & $\% 47$ increases in CAD severty \\
\hline $\begin{array}{l}\text { Vitek L et al. } \\
2002\end{array}$ & $\begin{array}{l}\text { With Gilbert } \\
\text { Syndrome }\end{array}$ & 50 & Increase serum bilirubin & $\% 2$ decrease of CAD prevalence \\
\hline $\begin{array}{ll}\text { Novotny } & \text { L } \\
\text { and Vitek } & \text { L. } \\
2003 & \\
\text { (meta- } & \\
\text { analysis) } & \end{array}$ & $\begin{array}{l}\text { With Gilbert } \\
\text { Syndrome }\end{array}$ & & $\begin{array}{l}1.0 \mu \mathrm{mol} / \mathrm{L} \text { increases in } \\
\text { serum bilirubin }\end{array}$ & $\begin{array}{l}\% 6.5 \text { decreases in } \\
\text { diseases (CVD) }\end{array}$ \\
\hline $\begin{array}{l}\text { Huang ss et al. } \\
2010\end{array}$ & $\begin{array}{l}\text { Cardiac } \\
\text { syndrome }\end{array}$ & 108 & Lowest serum bilirubin & $\begin{array}{l}\text { Higher myocardial infarction(MI), } \\
\text { ischemic stroke, unstable angına (UAP) }\end{array}$ \\
\hline $\begin{array}{l}\text { Huang FY et } \\
\text { al. } 2017\end{array}$ & CAD & 3013 & Serum bilirubin & $\begin{array}{l}\text { Pozitif correlation with short-term } \\
\text { mortality in AMI } \\
\text { Negatif correlation with long- } \\
\text { term mortality in CAD and UAP }\end{array}$ \\
\hline $\begin{array}{l}\text { Tanak M et al. } \\
2009\end{array}$ & \begin{tabular}{l}
\multicolumn{2}{l}{ Cardiovasculer } \\
Heart disease \\
(CHD)
\end{tabular} & 637 & Serum bilirubin & $\begin{array}{l}\text { Associated with coronary artery } \\
\text { calcification (CAC) score }\end{array}$ \\
\hline $\begin{array}{l}\text { Kang Sj et al. } \\
2013\end{array}$ & Non-CAD & 2682 & $\begin{array}{l}\text { Higher Serum bilirubin } \\
(>1.2 \mathrm{mg} / \mathrm{dL})\end{array}$ & $\begin{array}{l}\text { Lower prevalence }>\% 50 \\
\text { coronary plaque }\end{array}$ \\
\hline $\begin{array}{l}\mathrm{Xu} \mathrm{C} \text { et al. } \\
2019\end{array}$ & $\begin{array}{l}\text { Acute coronary } \\
\text { syndrome }\end{array}$ & 533 & Serum bilirubin & $\begin{array}{l}\text { Association with revascularization, } \\
\text { acute heart failure and mortaliy }\end{array}$ \\
\hline $\begin{array}{l}\text { Yang L et al. } \\
2019 \\
\text { (meta- }\end{array}$ & $\begin{array}{l}\text { Atherosclerotik } \\
\text { cardiovasculer } \\
\text { disease (ASCVD) }\end{array}$ & $\begin{array}{l}323,89 \\
1\end{array}$ & Serum total bilirubin & $\begin{array}{l}\text { Negative association with cardiovasculer } \\
\text { mortality, major advers cardiac events } \\
\text { and prognosis of AMI }\end{array}$ \\
\hline analysis) & & & Lower serum total bilirubin & $\begin{array}{l}\text { Corelation with peripheral artery } \\
\text { disease(PAD) }\end{array}$ \\
\hline $\begin{array}{l}\text { Perlstein TS et } \\
\text { al. } 2008\end{array}$ & NHANES & 7000 & $\begin{array}{l}0.1 \mathrm{mg} / \mathrm{dL} \text { increases in } \\
\text { serum bilirubin }\end{array}$ & $\% 6$ decrease in incidence of PAD \\
\hline $\begin{array}{l}\text { Zhong k et al. } \\
2020\end{array}$ & $\begin{array}{l}\text { Asymptomatic } \\
\text { intracranial } \\
\text { atherosclerosis } \\
\text { (aICAS) }\end{array}$ & & Serum bilirubin & Negative association wtih aICAS \\
\hline $\begin{array}{l}\text { Lin LY et al. } \\
2009\end{array}$ & $\begin{array}{l}\text { Methabolic } \\
\text { syndrome(MS) }\end{array}$ & 7177 & Lower serum bilirubin & Higher prevalence of MS \\
\hline $\begin{array}{l}\text { Cheriyath P et } \\
\text { al. } 2010\end{array}$ & NHANES & 15,867 & Increases in total bilirubin & $\% 26$ decrease in diabetes risk \\
\hline $\begin{array}{l}\mathrm{Fu} \text { YY et al. } \\
2010\end{array}$ & $\begin{array}{l}\text { Hyperbilirubinem } \\
\text { ic Gunn rats }\end{array}$ & & $\begin{array}{l}\text { Pretreatment with } 0.1 \\
\text { mg/dL bilirubin }\end{array}$ & $\begin{array}{l}\text { Decrease cell death and apoptosis in the } \\
\text { cell line of rat insulinoma }\end{array}$ \\
\hline $\begin{array}{l}\text { Jiraskova A et } \\
\text { 1. } 2011\end{array}$ & Type 2 diabetes & 700 & $\begin{array}{l}0.1 \mu \mathrm{mol} / \mathrm{L} \text { increase in } \\
\text { serum bilirubin }\end{array}$ & $\begin{array}{l}\text { Reduce the likelihood of developing } \\
\text { diabetes }\end{array}$ \\
\hline $\begin{array}{l}\text { Vitek et al. } \\
2002\end{array}$ & Gilbert syndrome & & Increased serum bilirubin & $\begin{array}{l}\text { Increased total antioxidant capacity } \\
\text { (TAS) }\end{array}$ \\
\hline $\begin{array}{l}\text { Hwang } \mathrm{Hj} \text { et } \\
\text { al. } 2011\end{array}$ & Healty people & 2307 & Total and direct bilirubin & Negative association with serum CRP \\
\hline $\begin{array}{l}\text { Seung JK et } \\
\text { al. } 2013\end{array}$ & CAD & 2862 & $\begin{array}{l}\text { Higher serum bilirubin } \\
(>1.2 \mathrm{mg} / \mathrm{dL})\end{array}$ & Lower serum CRP \\
\hline
\end{tabular}


reported a strong relationship between bilirubin and diabetes. In the study of 15,876 participants from NHANES between 1999 and 2006, total bilirubin increase after age adjustment was associated with a $26 \%$ decrease in diabetes risk (or $0.74,95 \% \mathrm{CI}$ $0.64-0.88)$ [26].

This relationship has also been supported by studies on animals. Korean researchers reported that hyperbilirubinemic Gunn rats showed significant resistance to developing diabetes after exposure to intraperitoneal streptozosine compared to their normobililubinemic offspring. It has also been found that pretreatment with bilirubin $(0.1 \mathrm{mg} / \mathrm{dL})$ in the cell line of a rat insulinoma reduces cell death and apoptosis caused by streptosis and suppresses $\mathrm{H}_{2} \mathrm{O}_{2}$ production [27]. A study published in 2011 covered more than 500 patients with type 2 diabetes mellitus and 200 healthy controls. The findings showed that serum bilirubin levels were low and that the probability of developing diabetes increased every $1,0 \mu \mathrm{mol} / \mathrm{L}$ [28].

Recently reported that higher serum concentrations of bilirubin are associated with a decreased risk of developing CAD and all-cause death in diabetic patients. So serum bilirubin improves the may be risk predictions of cardiovascular and total death in diabetic patients [29]. In conclusion, low serum total bilirubin levels were associated with a significant increase in the risk of diabetes in patients with impaired fasting glucose [27]. In observational studies being included in metabolic syndrome and diabetes, including meta-analyses involving participants almost one million, the negative relationship between serum bilirubin levels and metabolic syndrome with diabetes has been shown once more [30]. Finally, a meta-analysis showing the relationship between bilirubin and atherosclerosis was published. According to the findings obtained in this meta-analysis, higher bilirubin significantly has improved the good prognosis of atherosclerotic cardiovascular diseases [22].

\section{Gilbert Syndrome and Bilirubin}

Last two decades to investigate the link between bilirubin and reduced risk of cardiovascular disease, the relationship between oxidative stress, inflammation, and markers of vascular dysfunction and bilirubin has been clinically investigated [5]. After all, many beneficial advised linked to moderate elevations of serum bilirubin have been recognized. Thus, Gilbert Syndrome provides invaluable evidence for investigating the anti atherosclerotic effects of bilirubin.

Also the effects of hyperbilirubinemia on decreasing plasma levels of advanced glycosation end products (AGE) that contribute to atherosclerosis have been investigated [31]. As it is known, increased AGE formation in the collagen in the artery wall contributes to the Atherosclerosis process by increasing the rigidity in the vessel structure. In addition, AGE-bound collagen found in the vascular structure accelerates the formation of plaque by binding to LDL. In one of the clinical trials related to Gilbert Syndrome, serum levels AGE were significantly lower than the in these hyperbilirubinemic individuals [31]. In another study involving subjects with Gilbert Syndrome, with kidney diseases were significantly lower compared with the control group [32].

The relationship between bilirubin and total antioxidant capacity (TAS) has been reported in some studies. While, Vitek et al published in 2002 in a study involving Gilbert cases, and the control group. They found that TAS differed significantly between these groups. TAS was significantly higher in patients with Gilbert Syndrome compared with control cases. As showed in the other in vitro experiment, serum levels of TAS was might be associated with increased bilirubin concentration [12].

\section{Chronic inflammation and Bilurubin}

The elevation of bilirubin concentration in plasma is well known as a marker of hemolytic conditions, liver damage or bile-duct impairment. Endothelial activation and recruitment of inflammatory cells are two pivotal steps in the development of atherosclerotic lesions [2,3]. Especially, also the production of bilirubin in peripheral tissues has been proposed to be protective the anti-inflammatory effect of bilirubin was already observed in hyperbilirubinemic rats. Also in vitro studies demonstrated that bilirubin prevents $\mathrm{TNF} \alpha$-induced leukocyte adhesion to endothelial cells by reducing the expression of pro inflammatory molecules [2-4].

There are also studies focusing on the relationship between $\mathrm{C}$-reactive protein (CRP) and bilirubin, a marker that reflects chronic vascular inflammation. For example a crosssectional study of 2307 healthy Korean adults found that total and direct bilirubin elevations were associated with low serum CRP levels. After adjusting age, body mass index, hypertension, diabetes, hypercholesterolemia, cardiovascular disease, aspirin, smoking, alcohol and regular exercise, the negative association of CRP with both total and direct bilirubin was maintained. Thus it is hypothesized that low serum CRP levels may be due to the antioxidant and antiinflammatory effects of bilirubin metabolism [33]. In another study $(n=2862)$, those with a high serum bilirubin level $(>1,2 \mathrm{mg} / \mathrm{dL})$ had a lower CRP level than those with a low serum bilirubin level $(<1,2 \mathrm{mg} / \mathrm{dL})$ (34). Slight increases in plasma total bilirubin concentrations $(1.53 \pm 0.48$ $\mathrm{mg} / \mathrm{dl}$ ) have been reported to preserve flowmediated vasodilation compared to subjects with low levels of plasma bilirubin $(0.40 \pm$ $0.08 \mathrm{mg} / \mathrm{dl}(10,35)$. Also recently repoted that the serum total bilirubin level was found to be $0.41 \pm 0.21 \mathrm{ng} / \mathrm{dL}$ in the severe erectile dysfunction, $0.43 \pm 0.19 \mathrm{ng} / \mathrm{dL}$ in the moderate erectile dysfunction, and $0.48 \pm 0.11 \mathrm{ng} / \mathrm{dL}$ in the mild erectile dysfunction groups. Also the prevalence of multiple sclerosis was $6.6 \pm 1.2 \%$ in the group with the lowest bilirubin concentration, while bilirubin concentration was $2.1 \pm 1.9 \%$ in the highest bilirubin concentration group [36].

Bilirubin is able to protect against atherosclerotic diseases by means of different metabolic pathways? We can only answer this question by looking at studies related to Hem metabolism.

\section{Heme and Atherosclerosis}

Heme, an amphipathic iron-protoporphyrin complex, is one of the most important prosthetic groups on Earth, which serves as an oxygen transporter and participates in various oxido/reductive processes in aerobic and anaerobic cell metabolism. However, free heme released from the safe sanctuary area of heme proteins triggers a number of adverse events. In last two decades, several reports revealed the detrimental role of heme in neuronal damage and the potential role of heme in health and disease. Heme, due to its amphipathic nature, shows high affinity towards biological membranes, sensitizing them towards reactive oxygen species and leading to the oxidative damage of membrane lipids, cell lysis, genomic, and mitochondrial DNA damage [34]. For these reason recently administration of FDA-approved hexyl 5-aminolevulinate hydrochloride has begun to be used in clinical trials to produce anti-inflammatory carbon monoxide and bilirubin in atherosclerosis [37].

\section{Bilirubin and Heme Oxygenases}

Heme oxygenase is the first, rate-limiting enzyme in heme degradation pathway, with two major isoforms of heme oxygenase identified. First Heme oxygenase-1 is inducible whereas, expressed only under oxidative stress or when heme oxygenase-2 [38,39]. 
There are several experimental conditions where hem oxygenases-1 provides defense for cells and tissues. Heme oxygenases-1 catalyzes the opening of the prothoporphyrinic ring of heme, generating biliverdin, free iron and carbon monooxide (CO) (Figure 3). Moreover, biliverdin is considered to be an endogenous antioxidant in several clinical conditions [37]. CO has anti-apoptotic and antiinflammatory activities. While $\mathrm{CO}$ is an anti-inflammatory and anti-apoptotic gas molecule. The scientific importance of $\mathrm{CO}$ is increasing, since quite a lot of work proves its anti-inflammatory effects. Considering the protective effect of Heme oxygenases, it is a logical explanation that end-products of heme degradation, bilirubin, biliverdin, and $\mathrm{CO}$ are responsible for the beneficial action. The generation of free iron is potentially highly toxic but, under physiological conditions, a parallel induction of the heavy chain of ferritin, and the activation of membrane Fe-ATPase transporters occur. To eliminate the redox active free iron, cells rapidly express ferritin. The antioxidant character of ferritin depends on its ferroxidase activity and iron sequestering capability [39]. The possible mechanisms of underlying the relationship between high bilirubin and decreased atherosclerosis as monitored: bilirubin could effectively block the generation of cellular reactive oxygen species and intercellular adhesion molecule. High serum bilirubin levels resists for myeloperoxidase-induced oxidation and to prevent the formation of atherosclerosis; and higher bilirubin also has related for an anti-inflammatory effect on atherosclerotic process [37] (Figure 4). It has clearly been shown that unconjugated bilirubin mimics the hypolipidemic activity of fenofibrate. These data show that, in the vessel wall, the activity of bilirubin on lipid metabolism is complex and merits further investigation. As recently reviewed, bilirubin prevent platelets aggregation due its ability to interfere with the surface expression of adhesion molecules and its antioxidant activity, thereby supporting a role played in the prevention of hypercoagulability and thrombosis [39].

Figure 3: Heme oxygenase and products.

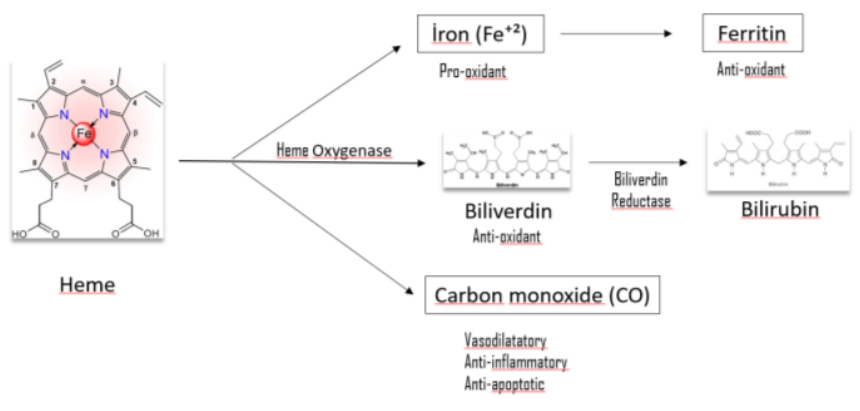

Figure 4: Enzymatic reactions of bilirubin generation and cytoprotection

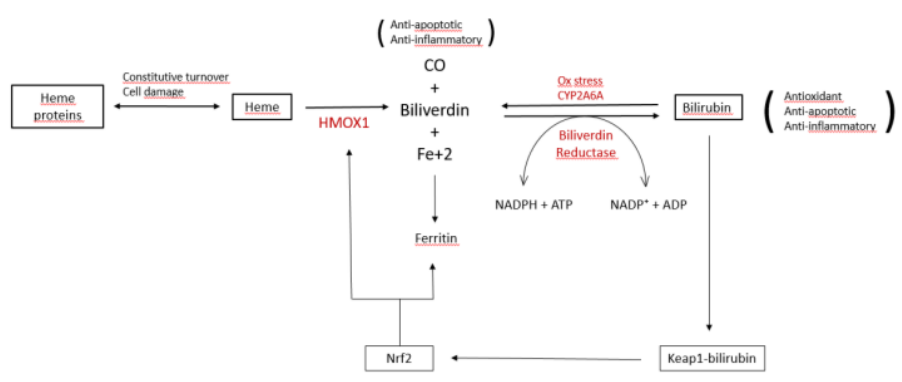

HMOX1:Heme oxygenases1, CO:Carbon monoxide, Nrf2:Nuclear factor erythroid-2 related factor, Keap1:Kelch ECH-associating protein 1.

Heme oxygenases 1 catalyzes the degradation of heme groups to $\mathrm{CO}$, $\mathrm{Fe} 2+$ and biliverdin, the latter subsequently converted to bilirubin by biliverdin reductase. By reaction with oxidant species, bilirubin is oxidized back to biliverdin, amplifying the antioxidant effect. Bilirubin and $\mathrm{CO}$ exert anti-apoptotic and anti-inflammatory activity. $\mathrm{Fe} 2+$ is quenched by the heavy chain of ferritin, and further released to form heme. A positive feedback of cytoprotection can be generated by the ability of bilirubin to bind nucleophiles such as thiol reactive cysteines on Keap1, favoring Nrf2-dependent HMOX1 gene transcription.

\section{Conclusions}

In this review, several experimental and clinical studies investigating the relationship between atherosclerotic diseases and bilirubin and the effects of bilirubin on the atherosclerotic process were examined. Although different results are obtained in some studies, the protective properties of bilirubin are observed at every stage of the Atherosclerosis process. Clinical studies examining the relationship between Bilirubin and atherosclerotic diseases have suggested that low serum bilirubin concentrations are associated with increased risk of.

\section{References}

1. Kang SJ, Leea C, Kruzliakb P. Effects of serum bilirubin on atherosclerotic processes. Annals of Medicine. 2014;46:138-47.

2. Vítek L. The role of bilirubin in diabetes, metabolic syndrome, and cardiovascular diseases. Front Pharmacol. 2012;3:55.

3. Lin Y, Wang S, Yang Z, Gao L, Zhou Z, Yu P, Wu B.Bilirubin alleviates alum-induced peritonitis through inactivation of NLRP3 inflammasome. Biomed Pharmacother. 2019;116:108973.

4. Kang SJ, Lee C, Kruzliak P.Effects of serum bilirubin on atherosclerotic processes. Ann Med. 2014; 46:138-47.

5. Yilmaz N, Cicek HK, Celik A, Davutoglu V. Diagnostic value of bilirubin concentrations compared with novel and traditional biomarkers in atherosclerosis with coronary artery disease. Saudi Med J. 2006;27:1262-4

6. Stocker R, Yamamoto Y, McDonagh AF, Glazer AN, Ames BN. Bilirubin is an antioxidant of possible physiological importance. Science. 1987;235:1043-6.

7. Wu TW, Fung KP, Yang CC. Unconjugated bilirubin inhibits the oxidation of human low density lipoprotein beter than Trolox. Life Sci. 1994;54:477-81.

8. Baranano DE, Rao M, Ferris CD, Snyder SH. Biliverdin reductase: a major physiologic cytoprotectant. Proc Natl Acad Sci U S A. 2002;99:16093-8.

9. Gazzin S, Vitek L, Watchko J, Shapiro SM, Tiribelli C. A novel perspective on the biology of bilirubin in health and disease. Trends Mol Med. 2016;22:758-768.

10. Kunutsor SK, Kieneker LM, Burgess S, Bakker SJL, Dullaart RPF. Circulating total bilirubin and future risk of hypertension in the general population: the prevention of renal and vascular endstage disease (prevend) prospective study and a mendelian randomization approach. J Am Heart Assoc. 2017;6:e006503.

11. Schwertner HA, Jackson WG, Tolan G. Association of low serum concentration of bilirubin with increased risk of coronary artery disease. Clin Chem. 1994;40:18-23.

12. Vitek L, Jirsa M, Brodanova M, Kalab M, Marecek Z, Danzig V, et al. Gilbert syndrome and ischemic heart disease: a protective effect of elevated bilirubin levels. Atherosclerosis. 2002;160:44956.

13. Novotny L, Vitek L. Inverse relationship between serum bilirubin and atherosclerosis in men: a meta-analysis of published studies. Exp Biol Med (Maywood). 2003;228:568 - 71

14. Huang SS, Huang PH, Leu HB, Wu TC, Lin SJ, Chen JW. Serum bilirubin predicts long-term clinical outcomes in patients with cardiac syndrome X. Heart. 2010;96:1227-32.

15. Huang FY, Peng Y, Huang BT, Yang Y, Pu XB, Chen SJ, et al. The correlation between serum total bilirubin and outcomes in patients with different subtypes of coronary artery disease. Clin Chim Acta. 2017;465:101-05.

16. Tanaka M, Fukui M, Tomiyasu K, Akabame S, Nakano K, Hasegawa $G$, et al. Low serum bilirubin concentration is associated with coronary artery calcifi cation (CAC). Atherosclerosis. 2009;206:287-91.

17. Kang SJ, Kim D, Park HE, Chung GE, Choi SH, Choi SY, et al. Elevated serum bilirubin levels are inversely associated with coronary artery atherosclerosis. Atherosclerosis. 2013;230:242-8.

18. Lapenna D, Ciofani G, Pierdomenico SD, Giamberardino MA, Ucchino S, Davì G. Association of serum bilirubin with oxidant 
damage of human atherosclerotic plaques and the severity of atherosclerosis. Clin Exp Med. 2018;18:119-24.

19. Frikha Z, Ferreira JP, Bozec E, McMurray JJV, Pitt B, Dickstein $\mathrm{K}$, et al. Relation of high serum bilirubin to short-term mortality following a myocardial infarction complicated by left ventricular systolic dysfunction (from the high-risk myocardial infarction database initiative). Am J Cardiol. 2018;121:1015-20.

20. Xu C, Dong M, Deng Y, Zhang L, Deng F, Zhou J, et al. Relation of direct, indirect, and total bilirubin to adverse long-term outcomes among patients with acute coronary syndrome. Am J Cardiol. 2019;123:1244-48.

21. Shen H, Zeng C, Wu X, Liu S, Chen X. Prognostic value of total bilirubin in patients with acute myocardial infarction: A metaanalysis. Medicine (Baltimore). 2019;98:e13920.

22. Yang L, Huan L, Jinbo L, Hongwei Z, Hongyu W. Is serum total bilirubin a predictor of prognosis in arteriosclerotic cardiovascular disease? :A meta-analysis. Medicine (Baltimore). 2019;98:e17544.

23. Perlstein TS, Pande RL, Beckman JA, Creager MA. Serum total bilirubin level and prevalent lowerextremity peripheral arterial disease - National Health and Nutrition Examination Survey (NHANES) 1999 to 2004. Arterioscler Thromb Vasc Biol. 2008;28:166-172.

24. Zhong K, Wang X, Ma X, Ji X, Sang S, Shao S, et al. Association between serum bilirubin and asymptomatic intracranial atherosclerosis: results from a population-based study. Neurol Sci 2020.

25. Lin LY, Kuo HK, Hwang JJ, Lai LP, Chiang FT, Tseng CD, et al Serum bilirubin is inversely associated with insulin resistance and metabolic syndrome among children and adolescents. Atherosclerosis. 2009;203:563-8.

26. Cheriyath P, Gorrepati VS, Peters I, Nookala V, Murphy ME, Srouji N, et al. High total bilirubin as a protective factor for diabetes mellitus: an analysis of NHANES data from 1999-2006. J Clin Med Res. 2010;2:201-6.

27. Fu YY, Kang KJ, Ahn JM, Kim HR, Na KY, Chae DW, et al. Hyperbilirubinemia reduces the streptozotocin-induced pancreatic damage through attenuating the oxidative stress in the Gunn rat. Tohoku J Exp Med. 2010;222:265-73.

28. Jiraskova A, Jovanovska J, Skrha J, Vitek L. Association of low bilirubin levels and promoter variations in UGT1A1 gene with diabetes mellitus type 2 (abstract). Hepatol Int. 2011;5:37.

29. Yang M, Ni C, Chang B, Jiang Z, Zhu Y, Tang Y, et al Association between serum total bilirubin levels and the risk of type 2 diabetes mellitus. Diabetes Res Clin Pract. 2019;152:2328.

30. Nano J, Muka T, Cepeda M, Voortman T, Dhana K, Brahımaj A, et al. Association of circulating total bilirubin with the metabolic syndrome and type 2 diabetes: a systematic review and metaanalysis of observational evidence. Diabetes Metab. 2016;42:38997.

31. Peppa M, Uribarrı J, Vlassara $H$. The role of advanced glycation end products in the development of atherosclerosis. Curr Diab Rep. 2004;4:31-36.

32. Vitek L, Kraslova I, Muchova L, Novotny L, Yamaguchı T. Urinary excretion of oxidative metabolites of bilirubin in subjects with Gilbert Syndrome. J Gastroenterol Hepatol. 2007;22:841-45.

33. Hwang HJ, Lee SW, Kım SH. Relationship between bilirubin and C-reactive protein. Clin Chem Lab Med. 2011;49:1823-28.

34. Kang SJ, Kim D, Park HE, Chung GE, Choi SH, Choi SY, et al. Elevated serum bilirubin levels are inversely associated with coronary artery atherosclerosis. Atherosclerosis. 2013;230:242-8.

35. Keskin E, Karabakan M, Bozkurt A, Hirik E, Karabulut I, Gunay $\mathrm{M}$, et al. Is there any relationship between serum levels of total bilirubin and the severity of erectile dysfunction? Urologia. 2018;85:106-10.

36. Erdogan D, Gullu H, Yildirim E, Tok D, Kirbas I, Ciftci O, Baycan ST, Muderrisoglu H.Low serum bilirubin levels are independently and inversely related to impaired flow-mediated vasodilation and increased carotid intima-media thickness in both men and women. Atherosclerosis. 2006 Feb;184:431-7.

37. Gáll T, Balla G, Balla J. Heme, heme oxygenase, and endoplasmic reticulum stress-a new insight into the pathophysiology of vascular diseases. Int J Mol Sci. 2019;20(15).

38. Nitti M, Furfaro AL, Mann GE. Heme Oxygenase Dependent Bilirubin Generation in Vascular Cells: A Role in Preventing Endothelial Dysfunction in Local Tissue Microenvironment? Front Physiol. 2020 29;11.23. eCollection 2020.
39. Kundur AR, Bulmer AC, Singh I.Unconjugated bilirubin inhibits collagen induced platelet activation. Platelets. 2014;25:45-50. 